\title{
PRESENCE, DISTRIBUTION AND EFFECT OF WHITE, PINK AND PURPLE MORPHS ON POLLINATION IN THE ORCHID ORCHIS MASCULA
}

\author{
BERTRAND SCHATZ1,*, ROXANE DELLE-VEDOVE ${ }^{2}$, \\ and LAURENT DORMONT ${ }^{1}$
}

\author{
${ }^{1}$ Centre d'Ecologie Fonctionnelle et Evolutive (CEFE), UMR 5175 CNRS, 1919 Route de Mende, 34293 Montpellier, France \\ ${ }^{2}$ Laboratoire de Génétique et Evolution des Populations Végétales (GEPV), UMR CNRS 8198, Université de Lille, Sciences et \\ Technologies, 59655 Villeneuve d'Ascq, France \\ *Corresponding author: bertrand.schatz@cefe.cnrs.fr
}

\begin{abstract}
How floral polymorphism of flowering plants can be maintained in evolutionary time has long intrigued ecologists and is still debated. In particular, how floral colour polymorphism influences reproductive success is still poorly understood. Here, we investigated the case of Orchis mascula, a deceptive orchid species in which the presence of rare white-flowered individuals is known to increase the percentage pollination of co-occurring coloured morphs. In a brief review, we report all the orchid species for which rare colour morphs are recorded and show that colour polymorphism occurs in most orchid genera occurring in France. In this study, more than 20,000 individuals of O. mascula were surveyed and some rare clear pink morphs were recorded. The frequencies of white-flowered and clear pink-flowered individuals were $0.59 \%$ and $0.28 \%$, respectively. These two rare-colour flowered individuals were not randomly distributed and restricted to a few populations. In addition, the presence of pink-flowered individuals and the use of experimental pink lures resulted in an increase in the percentage pollination of surrounding purple-flowered individuals, as previously shown for white-flowered individuals and white lures. These new observations favour kin selection as the means by which floral colour polymorphism is maintained in this species. We suggest conducting comparative studies of other species in order to evaluate the importance of this mechanism in orchid pollination and that of other plant families.
\end{abstract}

Keywords: floral colour polymorphism, Mediterranean orchids, pollination, pigment biosynthesis

\section{Introduction}

The maintenance of colour polymorphism has long intrigued ecologists. In particular, many flowering plants show substantial intraspecific variation in floral colour (Weiss 1995; Galen 1999; Warren and MacKenzie 2001). The key role of insects through pollinator-mediated selection is the current most often offered explanation for polymorphism in floral signals. Pollinators use diverse floral signals (flower colour, odour, size and shape) to detect flowers, and the various preferences of the different species of insect are a strong selective pressure for the evolution of the flowers they visit in search of rewards (Chittka and Raine 2006; Dormont et al. 2010a). However, recently it was suggested that intraspecific variation in floral traits may also reflect multiple and conflicting selection pressures. Herbivores or local abiotic conditions may also act directly or indirectly, through pleiotropic effects, as selective agents (Warren and MacKenzie 2001; Schemske and Bierzychudek 2007; Coberly and Rausher 2008; Wang et al. 2013). The relative role of these factors on floral polymorphism maintenance is still being debated as their importance as selective agents seems to vary among plant species.

Floral polymorphism is particularly widespread in orchids with a high variation in floral characters, which is generally associated with animal (mostly insect) pollination. Pollination through food deception is a strategy used by about one-third of all orchid species. In such deceptive species, variation in floral traits is expected to be high because pollinators learn to avoid common, unrewarding floral phenotypes (Schiestl 2005; Jersakova et al. 2006a; Dormont et al. 2010a). There is a great diversity of floral colours in orchids and many different kinds of pigments have been identified (Arditti 1992). There are cases of polymorphism in floral colour documented for a few orchids. The European orchid Dactylorhiza sambucina (Linné) Soó has yellow- and red-coloured morphs, in frequencies that reflect pollinator preference for the rare colour morph (Gigord et al. 2001). The maintenance of floral polymorphism in this rewardless orchid is explained in terms of negative frequency-dependent selection (Smithson and MacNair 1997; Gigord et al. 2001) and other recent hypotheses (Jersakova et al. 2006b; Smithson et al. 2007). In addition, the pan-tropical species of orchid, Calanthe sylvatica (Thou.) Lindl., has three colour morphs with white-, lilac-, and purple-coloured flowers, respectively. These three morphs differ in morphology, floral scent and distribution (altitude and habitat). These differences are hypothesized to reflect a process of on-going speciation (Juillet et al. 2010; Delle-Vedove et al. 2011). Polymorphism in floral colour may thus have different putative ecological explanations (adaptive strategy, on-going speciation), which largely remain to be discovered and elucidated. There are many orchids that exhibit colour polymorphism but there are few studies that explore how this polymorphism is maintained ecologically. For example, the extent to which colour polymorphism influences the reproductive success of such orchids remains poorly understood (Dormont et al. 2010a). 
White-coloured flower morphs are reported in various plant families. Insect pollinators have the ability to discriminate among colour morphs and exert a differential selection that may explain (at least partly) the different reproductive success of the colour morphs (Waser and Price 1981; Brown and Clegg 1984; Stanton et al. 1989; Odell et al. 1999; Jones and Reithel 2001; Raguso et al. 2003). Among the wide range of colour variants of orchid flowers, the occurrence of rare hypochromic inflorescences are regularly recorded in natural populations of the common coloured morph (Weiss 1995; Bournérias and Prat 2005; Dormont et al. 2010a). In orchids, the behavioural responses of pollinators to white inflorescences in populations of a coloured morph and the possible consequences for plant reproductive success have been poorly investigated (Koivisto et al. 2002; Ackerman and Carromero 2005). Dormont et al. (2010a) demonstrate for the European species Orchis mascula L. that the presence of white-flowered individuals results in a fourfold increase in the percentage pollination of neighbouring purple-flowered individuals. A similar effect is recorded when white lures are placed in natural populations of pure purple morphs. There is no difference in floral scent of purple- and white-flowered morphs. The maintenance of white-flowered mutants in O. mascula is hypothesized to be a result of kin selection, in which white morphs act as helpers by increasing the reproductive success of related purple individuals (Dormont et al. 2010b).

The "early purple orchid", O. mascula, is a food-deceptive orchid distributed throughout Europe, which typically has red-purple flowers. We recently discovered rare pink-flowered individuals occurring regularly in natural populations of purple-flowered individuals. We investigated this new case of colour polymorphism by addressing the following questions: (1) Do white-flowered individuals currently occur in other species of orchid in France? (2) What are the frequencies and the distributions of white-flowered and pink-flowered individuals in O. mascula populations? (3) Do pink-flowered individuals have a similar effect on percentage pollination as that already shown for white-flowered individuals? Based on our results, we offer new arguments to tentatively account for the maintenance of rare colour-flowered plants in orchids.

\section{Material and methods}

\section{Study sites and species}

The experiments were carried out in a mountainous area in south-central France, located about $70 \mathrm{~km}$ north of Montpellier. This study was carried out in area of $308 \mathrm{~km}^{2}$ $(22 \times 14 \mathrm{~km})$, which includes both the "Causse de Blandas" and "Causse de Campestre", and part of the "Causse du Larzac", which form a part of extensive limestone plateaux.

Orchis mascula L. is a perennial non-rewarding species of orchid, widely distributed in Europe, western Asia and northern Africa. Inflorescences consist gener- ally of 5-20 purple flowers. In some populations, a few white-flowered (Dormont et al. 2009) and pink-flowered individuals occur mixed with the purple-flowered individuals. O. mascula flowers depend on being pollinated by insects (Nilsson 1983; B. Schatz unpublished) and are visited and pollinated by several hymenoptera (bumblebees, cuckoo bumblebees, solitary bees) (Nilsson 1983; Bournerias and Prat 2005; Cozzolino et al. 2005; Dormont et al. 2010a). Flowering occurs early in spring, and $O$. mascula is known to exploit newly emerged insect pollinators, suggesting that pollination in this species is effected mainly by visits of naïve, inexperienced insects (Nilsson 1983; Van der Cingel 1995; Dormont et al. 2010a). Increased abundance of pollinators in the vicinity of nectariferous co-flowering species (van der Cingel 1995; Johnson et al. 2003) is unlikely to be an important factor in the reproductive success of $O$. mascula, as at our study sites there were very few other plants flowering early in the year when $O$. mascula flowers.

\section{Census of white-flowered and "chlorantha" morphs in species of orchid in France}

In metropolitan France, we recorded all the species of orchid that have white-flowered morphs (entirely albino flowers) or "chlorantha" morphs (the labellum is yellow-green) (Figs 1 and 2; see discussion for definition of these terms) based on records of personal field observations, naturalist books and photographs found on the web sites of several amateur orchid enthusiasts. We excluded from this census species or genera displaying classically natural white or green flowers in France (Chamorchis, Coeloglossum, Corallorhiza, Listera, Gennaria, Goodyera, Hammarbya, Herminium, Liparis, Listera, Malaxis, Platanthera, Pseudorchis, Spiranthes). In other words, this census included 153 species and subspecies of the 174 orchids that are included in the guide book to French orchids (Bournérias and Prat 2005). In certain genera, such as Dactylorhiza sp., Himantoglossum sp. and Neotinea sp., there is a typical dominant colour morph, but some individuals also exhibit many intermediate floral colours. In such genera, white morphs sometimes occurred in natural populations of coloured morphs and these were recorded. We encourage readers to contact us if they have additional data.

\section{Frequency and distribution of colour variants in populations of O. mascula}

In the area studied, all the individual plants of $O$. mascula were located and surveyed. The different populations, which typically consisted of 20 to 100 individuals, were recorded separately. Populations were patchy distributed and separated from each other by at least $50 \mathrm{~m}$. In the same area were groups of populations, including 17 to 37 populations, separated by at least $500 \mathrm{~m}$ (usually $1 \mathrm{~km}$ or more), which were also surveyed. The presence of white-flowered and pink-flowered individuals was recorded in each of the above populations. 

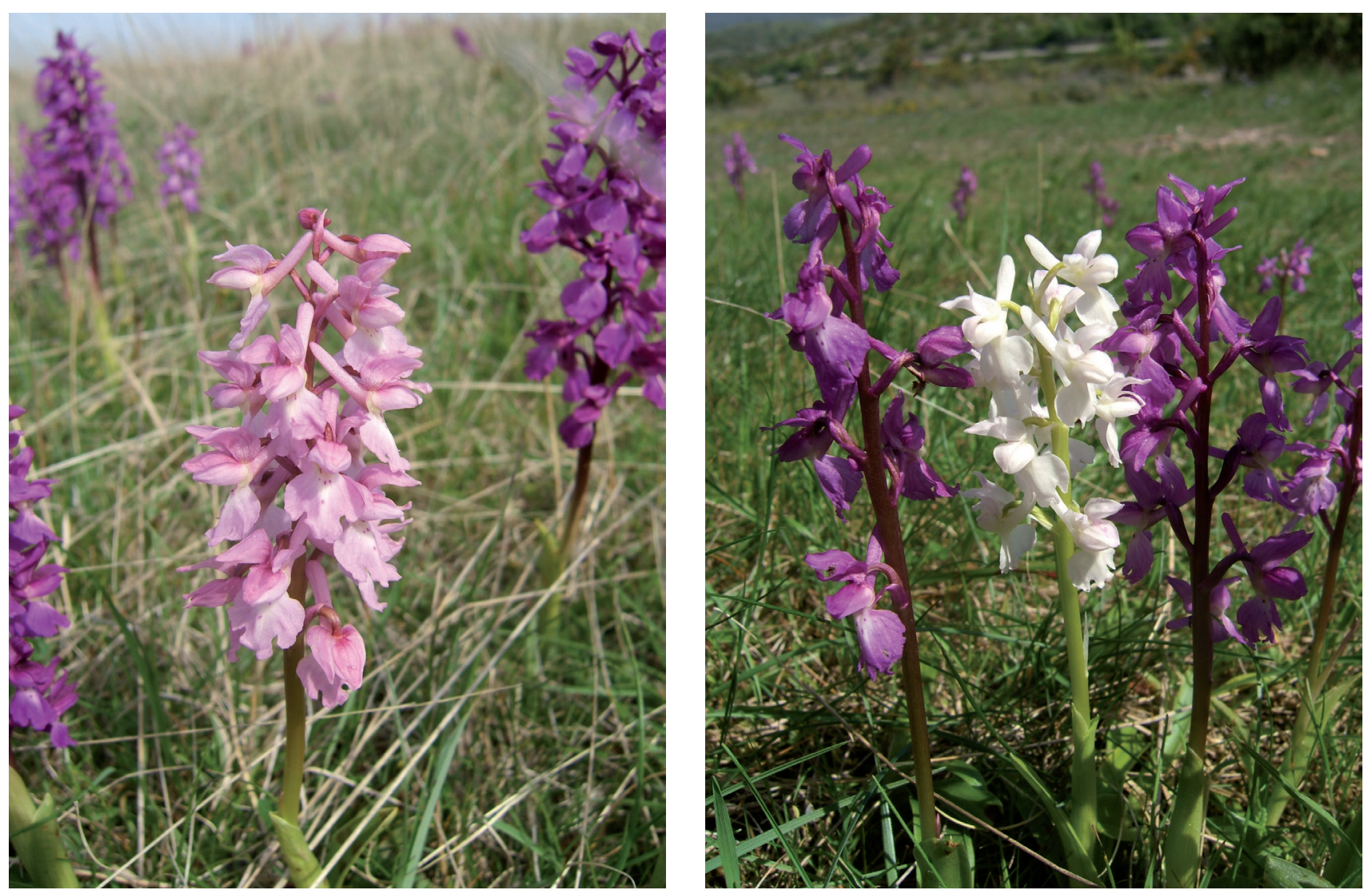

Fig. 1 White- and pink-flowered individuals in natural populations of purple individuals of Orchis mascula.
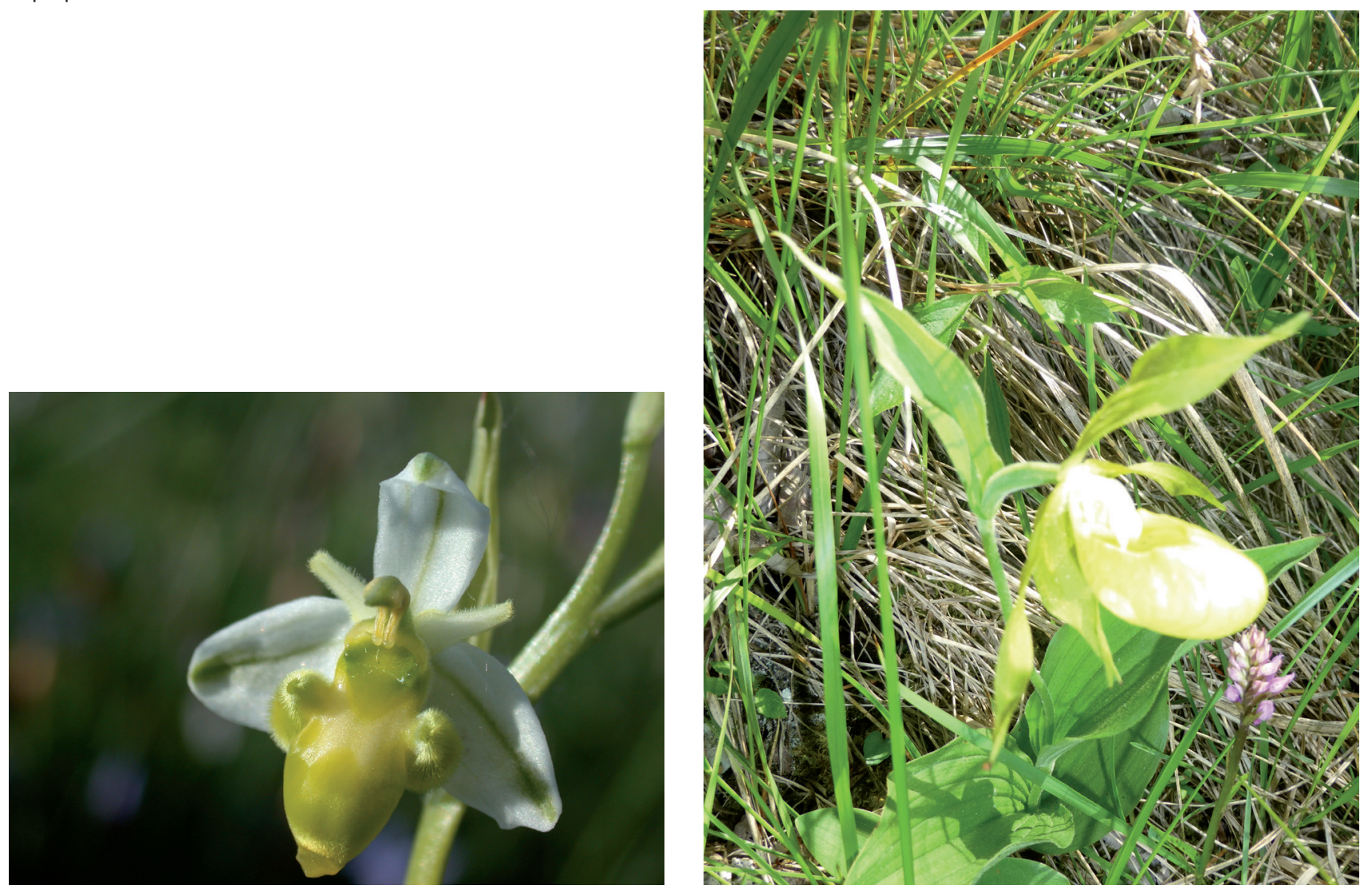

Fig. 2"Chlorantha" morphs of Ophrys scolopax (left) and Cypripedium calceolus (right). 


\section{Effect of rare colour-flowered individuals on percentage pollination of 0 . mascula}

The role of visual cues in attracting pollinators to flowers of $O$. mascula was estimated by using visual lures during field bioassays. We used white ping-pong balls to mimic white-flowered morphs in a population of natural purple-flowered individuals. This white, spherical standardized object is roughly similar in size to an $O$. mascula inflorescence (Dormont el al. 2010a). Each white ping pong ball was fixed to a wire shaft made of dark green metal, adjusted so that the height of the lure was equal to the mean height of surrounding $O$. mascula purple inflorescences. We placed these lures in populations of purple-flowered individuals at frequencies similar to the mean natural frequency of white inflorescences recorded in mixed populations. The populations of purple plants used in this experiment were selected at random from all the populations of only purple-flowered individuals. The visual lures were placed at random in each population sampled at the very beginning of the flowering period and left there for the whole flowering period.

The reproductive success of plants was assessed by comparing the mean percentage fruit set of seven populations in the area studied: Three populations were natural populations including 1) only purple-flowered individuals (12 populations, 255 individuals, 3736 flowers), 2) purple-flowered individuals with a few white-flowered individuals (12 populations, 255 individuals, 3791 flowers), 3) purple-flowered individuals with a few pink-flowered individuals (10 populations, 202 individuals, 2935 flowers). The four other populations were experimental populations, consisting of only natural purple-flowered individuals to which were added either 4) white lures mimicking white-flowered individuals (4 populations, 74 individuals, 668 flowers), 5) pink lures mimicking pink-flowered individuals (4 populations, 62 individuals, 710 flowers), 6) purple lures, as controls, mimicking pur- ple-flowered individuals (4 populations, 63 individuals, 578 flowers) or 7) green lures, as controls, mimicking the green environment surrounding the $O$. mascula flowers (4 populations, 59 individuals, 687 flowers).

In all populations and for each individual, at the end April (four weeks after placing the visual lures in the experimental populations) we counted the number of mature fruits and total number of flowers in each inflorescence, in order to evaluate percentage fruit set. For each of the seven types of population, individual fruit sets were pooled, because fruit set values were not significantly different among individuals of the same population. In this study, the fruit set was used to estimate plant fitness, but future experiments will also consider seed viability or seed germination. We estimated the influence of the type of population on the number of flowers per inflorescence and fruit set. As the data were not normally distributed (Shapiro-Wilk Test) we performed Permutational ANOVA. All analyses were performed using R 2.14.1 (R Development Core Team 2011).

\section{Results}

\section{Census of white-flowered and "chlorantha" morphs of species of orchids in France}

We recorded 36 species with white-flowered individuals (Table 1). These individuals are clearly distinct from the classical coloured-flowered individuals and no intermediate colour variant was noted. White-flowered individuals were mainly recorded in the species of three genera, namely Anacamptis sp. (11 species) and Dactylorhiza sp. (8 species). Most of the species with white morphs typically have purple (19 species) or pink (6 species) flowers and occurred mainly in open-habitats. To our knowledge, white-flowered individuals are not recorded in France in the 10 orchids that have yellow inflorescences, except in Cephalanthera damasonium.

Table 1 Literature review: presence of a white morph, together with other coloured variants, in different species of European orchids.

\begin{tabular}{|c|c|c|c|}
\hline $\begin{array}{l}\text { Species in which a white } \\
\text { morph is recorded }\end{array}$ & $\begin{array}{l}\text { Main floral } \\
\text { colour }\end{array}$ & $\begin{array}{l}\text { Presence of another } \\
\text { coloured variant }\end{array}$ & Reference \\
\hline Anacamptis pyramidalis & Purple & Yes & B Schatz (pers. obs.); Jouandoudet, 2004; A; B \\
\hline A. coriophora coriophora & Red-brown & No & B Schatz and R Souche (pers. obs.); Guérin et al. 2007; A; C \\
\hline A. coriophora fragrans & Red-brown & No & Dormont et al. (in revision.); B \\
\hline A. lactea & Pink points & No & Souche 2004 \\
\hline A. laxiflora & Purple & No & B \\
\hline A. longicornu & Purple & Yes & B Schatz (pers. obs.); B; C \\
\hline A. morio & Purple & Yes & B Schatz (pers. obs.); Jouandoudet 2004; Guérin et al. 2007; A; B; C \\
\hline A. palustris & Purple & No & B \\
\hline A. papilionacea expansa & Purple & No & Souche 2004; C \\
\hline A. papilionacea papilionacea & Purple & No & B \\
\hline A. picta & Purple & No & Souche 2004 ; B \\
\hline Cephalanthera rubra & Pink & No & $A$ \\
\hline C. damasonium & Yellow & No & Lemoine B and Pessotto L 2007 \\
\hline
\end{tabular}




\begin{tabular}{|c|c|c|c|}
\hline $\begin{array}{l}\text { Species in which a white } \\
\text { morph is recorded }\end{array}$ & $\begin{array}{l}\text { Main floral } \\
\text { colour }\end{array}$ & $\begin{array}{l}\text { Presence of another } \\
\text { coloured variant }\end{array}$ & Reference \\
\hline Dactylorhiza elata & Purple & No & Souche 2004 \\
\hline D. fuchsii & Purple & No & B Schatz (pers. obs.); Souche 2004; B; C \\
\hline D. incarnata & Purple & No & Souche 2004 \\
\hline D. maculata & Purple & No & B \\
\hline D. majalis & Purple & No & Souche 2004 \\
\hline D. saccifera & Purple & No & B Schatz (pers. obs.) \\
\hline D. savogiensis & Purple & Yes & B \\
\hline D. traunsteineri & Purple & No & E \\
\hline Epipogium aphyllum & Pink-white & No & B \\
\hline Gymnadenia conopsea & Pink & No & B Schatz (pers. obs.); Jouandoudet 2004; Souche 2004; B \\
\hline G. corneliana & Red & No & B \\
\hline Himantoglossum hircinum & $\begin{array}{l}\text { Green- } \\
\text { brown }\end{array}$ & No & B Schatz (pers. obs.) \\
\hline H. robertianum & $\begin{array}{c}\text { Pur- } \\
\text { ple-green }\end{array}$ & No & B Schatz (pers. obs.); B \\
\hline Orchis italica & Pink & No & Souche 2004 \\
\hline O. mascula & Purple & Yes & Dormont et al. 2009; Guérin et al. 2007; B; C \\
\hline O. purpurea & Purple & No & B Schatz (pers. obs.); Souche 2004; Guérin et al. 2007; B; C \\
\hline O. simia & Pink & Yes & Dormont et al. (in revision.); Souche 2004; Bournérias and Prat 2005; A; B; C \\
\hline O. militaris & Pink & No & B Schatz (pers. obs.); A; B; C \\
\hline Neotinea lactea & $\begin{array}{l}\text { Pur- } \\
\text { ple-white }\end{array}$ & Yes & $C, D$ \\
\hline N. maculata & $\begin{array}{l}\text { Pur- } \\
\text { ple-white }\end{array}$ & No & Souche $2004 ; C$ \\
\hline N. tridentata & $\begin{array}{l}\text { Pur- } \\
\text { ple-white }\end{array}$ & No & C \\
\hline N. ustulata & $\begin{array}{c}\text { Pur- } \\
\text { ple-white }\end{array}$ & No & B Schatz (pers. obs.) \\
\hline Traunsteinera globosa & Pink & No & N Juillet (pers. obs.) \\
\hline
\end{tabular}

Data were also recorded from the following websites:

A) http://www.orchidee-poitou-charentes.org/article2752.html

B) http://perso.numericable.fr/ durbphil/Lusus/LususCouleur.htm

C) http://www.elisajeanluc.fr/orchidées_nature/

D) http://www.guenther-blaich.de/wo_albin.htm

E) http://www.ryenats.org.uk/sandale/sandale.htm

For seven of the orchid species listed in the Table 1 (i.e. coloured-flowered species with the occasional white-flowered morph) no intermediate colour variant is described (Table 1). Such a new colour class would correspond to clear pink individuals, clearly distinct from the white and purple morphs, as in the case of O. mascula (Fig. 1).

"Chlorantha" morphs are recorded in 40 different species of orchid, notably in 28 Ophrys species (Table 2). The genera in which "chlorantha" morphs are recorded clearly differ from the other orchid genera in Table 1.

In total we recorded 76 species in which hypochromic individuals are recorded. These species are in all the genera with coloured species (see introduction) and are often common. Interestingly, no species of orchid in France is recorded as having both white and "chlorantha" morphs.

Table 2 Literature review: presence of 'chlorantha' morphs in different species of European orchids (see text for explanations, and Figure 2 for examples).

\begin{tabular}{lll}
\hline Species in which a "chlorantha" morph is recorded & \multicolumn{1}{c}{ Main floral colour } & \multicolumn{1}{c}{ Reference } \\
\hline Cypripedium calceolus & Violet and yellow & B Schatz, J Fonderflick and F Nicolé (pers. obs.) \\
Epipactis atrorubens & Purple-red & Jouandoudet 2004; B \\
E. helleborine & Green-red & Souche 2004; B \\
E. palustris & Red-white & B Schatz (pers. obs.) \\
E. purpurata & Green-purple & B \\
\hline
\end{tabular}




\begin{tabular}{|c|c|c|}
\hline Species in which a "chlorantha" morph is recorded & Main floral colour & Reference \\
\hline Limodorum abortivum & Violet & B Schatz (pers. obs.); D \\
\hline Nigritella rhellicani & Red & Souche 2004 \\
\hline Ophrys apifera & Multicolor & B Schatz (pers. obs.) \\
\hline O. apifera & Multicolor & $A$ \\
\hline O. araneola & Multicolor & $A ; B$ \\
\hline O. aranifera & Multicolor & A \\
\hline O. argentaria & Multicolor & Souche 2004 \\
\hline O. aurelia & Multicolor & C \\
\hline O. aveyronensis & Multicolor & C \\
\hline O. aymoninii & Multicolor & B Schatz (pers. obs.); Souche 2004; C \\
\hline O. bertolinii saratoi & Multicolor & Souche 2004 \\
\hline O. bombyliflora & Multicolor & B Schatz (pers. obs.); Souche 2004 \\
\hline O. classica & Multicolor & Souche 2004 \\
\hline O. exaltata arachnitiformis & Multicolor & Souche 2004 \\
\hline O. exaltata marzuola & Multicolor & Souche 2004 \\
\hline O. forestieri & Multicolor & $\mathrm{B} ; \mathrm{C}$ \\
\hline O. fuciflora & Multicolor & Souche 2004; A \\
\hline O. funerea & Multicolor & Souche 2004 \\
\hline O. gresivaudanica & Multicolor & B \\
\hline O. incubacea & Multicolor & Souche 2004 \\
\hline O. insectifera & Multicolor & B Schatz (pers. obs.); Souche 2004; Guérin et al. 2007; A \\
\hline O. litigiosa & Multicolor & Souche 2004; Guérin et al. 2007; C \\
\hline O. lutea & Multicolor & Guérin et al. 2007; A \\
\hline O. occidentalis & Multicolor & B \\
\hline O. passionis & Multicolor & C \\
\hline O. santonica & Multicolor & A \\
\hline O. scolopax & Multicolor & B Schatz (pers. obs.); Souche 2004; Guérin et al. 2007; B; C \\
\hline O. sicula & Multicolor & $\mathrm{C}$ \\
\hline O. speculum & Multicolor & C \\
\hline O. splendida & Multicolor & C \\
\hline O. sulcata & Multicolor & A \\
\hline Serapias lingua & Purple & E Sulmont and B Schatz (pers. obs.) \\
\hline S. neglecta & Purple & Souche 2004 \\
\hline S. parviflora & Purple & Souche 2004; A; B \\
\hline S. vomeracea & Purple & Souche 2004; A \\
\hline
\end{tabular}

Data were also recorded from the following websites

A) http://www.orchidee-poitou-charentes.org/article2752.html

B) http://perso.numericable.fr/ durbphil/Lusus/LususCouleur.htm

C) http://www.elisajeanluc.fr/orchidees_nature/

D) http://www.guenther-blaich.de/wo_albin.htm

\section{Frequency and distribution of colour variants in populations of O. mascula}

A total of 31 groups of $O$. mascula populations were surveyed during this study, involving 774 populations and 20090 individuals. The mean number of populations per group was $25.0 \pm 6.1($ mean $\pm S D)$. Considering all the 774 populations, the overall percentage of the different colour variants was as follows: $99.13 \%$ purple-flowered individuals $(\mathrm{n}=19914), 0.59 \%$ white-flowered individu- als $(\mathrm{n}=119)$ and $0.28 \%$ clear pink-flowered individuals ( $\mathrm{n}=57)$.

The white O. mascula morph was recorded in 89 of the 774 populations surveyed and occurred in only 9 of the 31 groups of populations. O. mascula populations including a white morph are thus not randomly distributed: a random distribution would have resulted in the presence of the white morph in each of the 31 population groups and in 2.0 to $4.3 \mathrm{O}$. mascula populations in each group 
$\left(\chi^{2}=31.07, \mathrm{df}=1, p<0.001\right)$. The pink O. mascula morph was recorded in 44 of the 774 populations and in only 7 of the 31 groups of populations. As for the white morph, populations including a pink morph are clearly not randomly distributed: a random distribution would have resulted in the presence of the white morph in 1.0 to 2.1 populations in each population group $\left(\chi^{2}=35.96\right.$; $\left.\mathrm{df}=1, p<0.001\right)$. The simultaneous presence, in the same group of populations, of populations with the white morph and other populations with the pink morph, was recorded in only two large population groups. The white and pink morph was recorded occurring sympatrically in only five populations in two different groups of populations.

\section{Effects of the presence of colour variants on the percentage pollination of 0 . mascula}

A total of 50 populations, including 973 individual plants of O. mascula and 13,105 flowers were surveyed to determine percentage fruit set. In natural populations, the average fruit set of purple-flowered individuals varied significantly depending on the presence or absence of other colour-morphs or lures (Permutational ANOVA: $\left.F_{(6.966)}=64.47, p=0.001\right)$. The average fruit set of purple-flowered individuals was $5.35 \pm 6.38 \%$ (mean \pm SD) in populations with only purple-flowered individuals. The average fruit set reached $26.49 \pm 22.23 \%$ in populations with a few white-flowered individuals and $27.8 \pm$ $14.49 \%$ in populations with a few pink-flowered individuals (Fig. 3). The mean number of fruits produced per inflorescence was significantly different among these three different types of population. Fruit sets of purple-flowered individuals were not significantly different in the populations with white flowers or with pink flowers, but fruit sets in both these populations were more than four times higher than that of purple-flowered individuals in populations where the latter were the sole morph. The mean number of flowers per inflorescence was not significantly different in the three colour morphs (permutational ANOVA: $\left.F_{(2,378)}=0.059, p=0.94\right)$ and was $14.65 \pm 4.50$ (mean $\pm \mathrm{SD})$ in the purple-coloured morph $(\mathrm{n}=255)$, $14.49 \pm 4.41$ in the white-coloured morph $(\mathrm{n}=87)$ and $14.46 \pm 4.65$ in the pink-coloured morph $(n=39$; the relative small sample size is due to the low frequency of this morph in the populations studied).

In experimental populations, the average fruit set of purple-flowered individuals was $29.19 \% \pm 26.62 \%$ in populations with white lures, $26.18 \% \pm 23.26 \%$ in populations with pink lures, $6.08 \% \pm 8.69 \%$ in populations with purple lures and $5.93 \% \pm 7.78 \%$ in populations with green lures (Fig. 3). Fruit sets of purple-flowered individuals were not significantly different in the populations with white lures or pink lures and not significantly different from the populations with white flowers or with pink flowers. Moreover, fruit sets of purple-flowered individuals were not significantly different in the populations with green lures or with purple lures and not significantly different in the populations with only purple flowers. However, fruit sets of purple-flowered individuals were more than four times higher in the populations with white or pink lures than in the populations with green or purple lures.

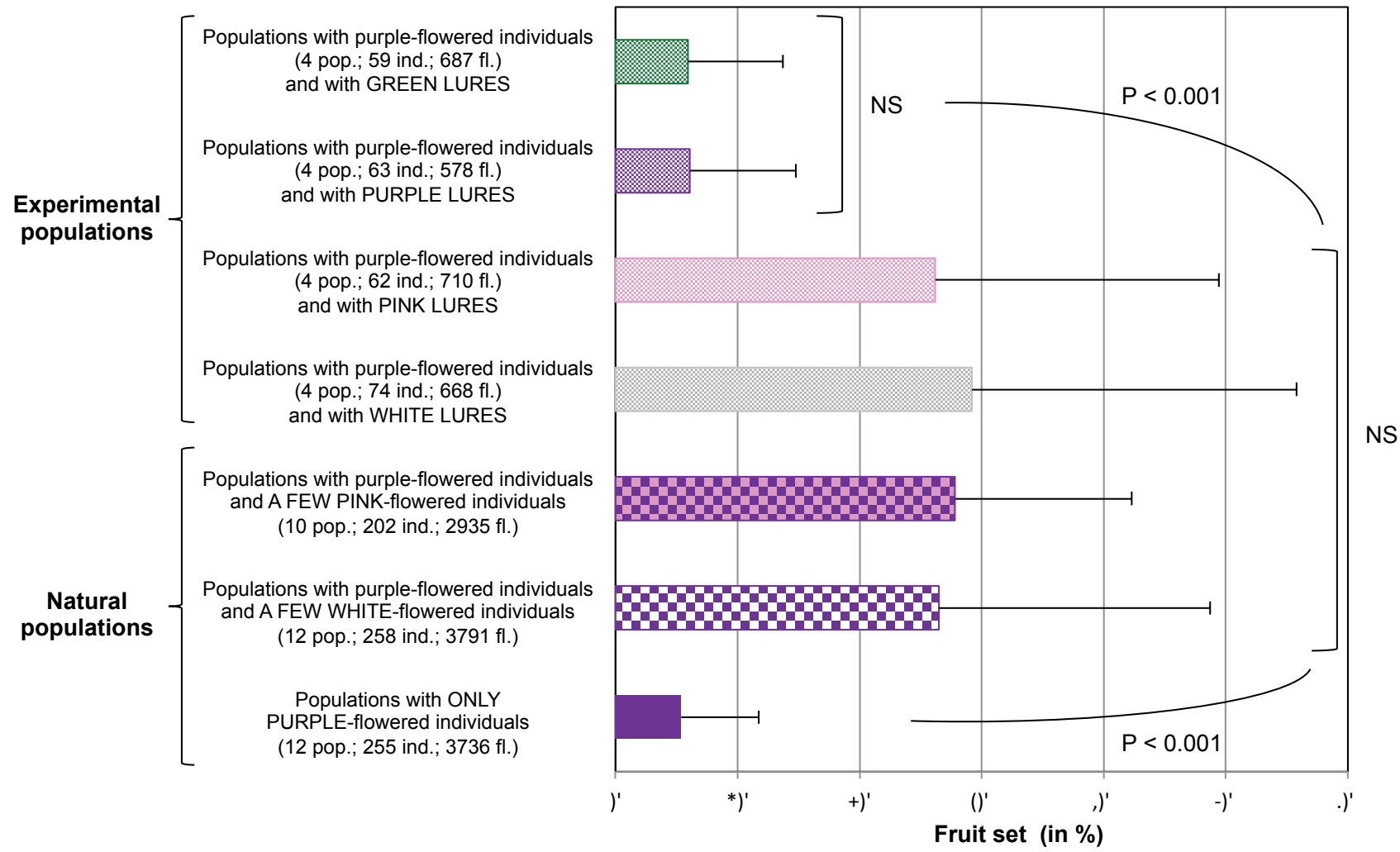

Fig. 3 Percentage fruit set (mean \pm SD) of purple-flowered individuals of Orchis mascula recorded in the seven types of populations studied. Results of the Permutational ANOVA are indicated on the figure (n.s.: non-significant). 


\section{Discussion}

This study provides three new arguments that help to tentatively explain the maintenance of rare colour-flowered plants in orchids: 1) the presence of rare hypochromic individuals is widespread in orchid species in France and this phenomenon both includes hypochromy, such as white and pink morphs, together with "chlorantha"; 2) in addition to the white-flowered morph, pink-flowered individuals also occurred in $O$. mascula populations, and the presence of this clear pink colour morph of O. mascula has a similar effect on percentage pollination as that previously recorded for the white morph (Dormont et al. 2010a); and 3) these two rare colour-flowered morphs of O. mascula occurred only in certain groups of populations, which is consistent with the predictions of the kin selection hypothesis as suggested for this species by Dormont et al. (2010b).

\section{Presence of rare hypochromic individuals}

This brief review of the literature revealed that white-flowered individuals are recorded in 36 species in France and this phenomenon certainly also occurs elsewhere in Europe. They occur in a total of nine genera (Anacamptis, Cephalanthera, Dactylorhiza, Epipogium, Gymnadenia, Himantoglossum, Orchis, Neotinea and Traunsteinera). Interestingly, these nine genera share a common floral trait: the flowers are generally purple or pink and in a few cases red. An intermediate class of colour (between white and the main colour) is recorded in some of these species, e.g. in O. mascula. Similar situations are reported for other species of plants, such as the Chalk Milkwort, Polygala calcarea, a plant that has violet, pink and white individuals (Schatz B., pers. obs.). The occurrence of such white coloured individuals is generally attributed to spontaneous mutations affecting floral pigmentation, which results in the complete absence of pigments in the flower parts (Waser and Price 1981; Epperson and Clegg 1987; Levin and Brack 1995). The occurrence of an intermediate class of colour, such as pink in O. mascula, may be explained by a partial attenuation of pigment biosynthesis. Finally, the presence of rare hypochromic individuals in orchids is different from the situation reported for other polymorphic species of orchid, in which the presence of distinct floral colour morphs (e.g., in D. sambucina and C. sylvatica) is due to the presence of different pigments.

'Chlorantha' morphs represent a second category of hypochromic individuals, characterized by yellow coloured floral parts. Some naturalists sometimes refer to 'viridism' to describe this phenomenon. To our knowledge, the use of this term is not supported by any scientific study. However, such 'chlorantha' morphs are reported in different groups of orchid taxa: 40 species in six different genera (Cypripedium, Epipactis, Limodorum, Nigritella, Ophrys and Serapias). Taken together, this literature review shows that rare hypochromic individuals are pres- ent in all genera with coloured flowers in France and in these species throughout Europe. These rare white-flowered individuals or 'chlorantha' individuals are sometimes described by naturalists as new subspecies (which are called 'albiflora,' 'alba,' 'flavescens'). This cannot be justified as these rare morphs occur in natural populations of coloured flowers and have similar ecological traits.

\section{Influence of rare floral signals on reproductive success}

To our knowledge, the presence of clear pink-flowered individuals in natural populations of coloured individuals, as reported here for $O$. mascula, has not previously been recorded. The presence of these rare coloured-flowered individuals clearly affects the percentage pollination of neighbouring purple-flowered individuals, as already shown for the white O. mascula morph (Dormont et al. 2010a). First, the overall average fruit set of $O$. mascula was low (mean fruit set 6\%), both for purple-morph individuals in pure purple populations and for the two rare colour individuals (white-morph and pink-morph), as reported in previous studies (Nilsson 1983; Van der Cingel 1995; Jacquemyn et al. 2008; Dormont et al. 2010a). Second, we show here that the presence of either co-occurring clear pink-flowered individuals or co-occurring white-flowered individuals had a similar effect, resulting in a significantly higher reproductive success of nearby purple-flowered individuals (mean fruit set 27\%). These results are incompatible with the hypothesis of negative frequency-dependent selection (NFDS) frequently assumed to explain floral colour polymorphism in non-rewarding orchids (Gigord et al. 2001): in this study we found that the common purple morph of $O$. mascula was fitter when the rare morph (pink or white) was present.

In a previous study, we showed that the chemical compositions of the floral volatiles emitted by the two colour morphs of $O$. mascula (white and purple) are not significantly different (Dormont et al. 2010a). Preliminary analyses of the scent emitted by the pink morph of $O$. mascula suggest that floral volatiles of the white, pink and purple morphs do not differ (Schatz et al. unpubl. data). Moreover, pink lures and pink-flowered individuals induced a similar increase in the percentage pollination of neighbouring purple-flowered individuals, which strongly suggest that visual signals alone probably play the key role in colour morph discrimination by insects, as previously shown for the white morph (Dormont et al. 2010a). White flowers are often reported has being less frequently pollinated than coloured flowers, but this is based on observations on nectar rewarding species (Waser and Price 1981; Brown and Clegg 1984; Odell et al. 1999). O. mascula is a nectarless species, flowering early in spring when pollinators are attracted through food deception and also because of their inexperience. In other deceptive orchid species (Jersakova et al. 2006a), pollinators deceived by the absence of a reward in one morph tend to visit the other morph, a process globally increasing the total number of visits of the same species of orchid. The presence 
of contrasting colours within single plant populations has also been shown to be attractive to bumblebees (Spaethe et al. 2001; Lunau et al. 2006). The increase in percentage pollination, observed both when rare colour-flowered individuals are present and when lures are used, clearly demonstrates the attractiveness of rare white and clear pink colours for naive pollinators. In contrast, the use of purple- or dark green-coloured lures, placed in pure purple populations, had no effect on the reproductive success of neighbouring purple coloured individuals of $O$. mascula. These results confirm that colour contrast is an attractive signal that can increase pollinator visits to flowers. Thus, these two rare flower colours in O. mascula (white and pink) may act visual attractants for insects.

Do similar effects on percentage pollination occur in other polymorphic species of orchid with white-flowered individuals? In O. mascula, the fourfold increase in fruit set is linked to three factors: 1) the early flowering of this orchid and the naivety of the newly emerged pollinators, 2) the contrast between white and the current purple flower colour is pronounced in O. mascula; and 3 ) the deceptive strategy in $O$. mascula, which results in a very low fruit set (about 6\%). The effects on pollination in some other orchids growing in the same study area would be more difficult to evaluate because they differ greatly in their biology. For example, the orchid Dactylorhiza fuschii flowers in June, has relatively clear pink flowers and usually a high fruit set (locally about 80\%) (Schatz B. pers. obs.). The situation is similar in two other species: Anacamptis coriophora fragrans flowers in May, has red flowers and a high fruit set $(80 \%)$ due to its nectar rewarding strategy and Orchis simia flowers in May, has pink flowers and a high fruit set (locally about $80 \%$ ) (Dormont et al. submitted) in spite of having nectarless strategy (but see Schatz 2006; Schatz et al. 2010). These three factors appear to be important when attempting to detect an effect on the percentage pollination rate of the presence of white-flowered individuals.

\section{Maintenance of the rare white-flowered 0. mascula}

In this study we surveyed more than 20,000 individuals of $O$. mascula and determined the frequency of rare colours in purple populations as $0.28 \%$ for clear pink-flowered individuals and $0.59 \%$ for white-flowered individuals. Spontaneous mutations affecting floral pigmentation that result in white-flowered variants (and potentially pink variants) are thought to account for the presence of low frequencies of white individuals in natural populations of pigmented flowers (on average $0.1 \%$ in these studies) (Waser and Price 1981; Epperson and Clegg 1987; Levin and Brack 1995). The difference between the frequencies reported in the literature $(0.1 \%)$ and those recorded for $O$. mascula $(0.6 \%)$ has been tentatively attributed to the possible role of pollinators in plant reproductive success (Dormont et al. 2010a).

Dormont et al. (2010a; 2010b) hypothesized that the maintenance of variant white-flowered individu- als in populations of $O$. mascula might be attributed to kin selection (see also Hamilton 1964). The presence of white-flowered individuals might be regarded as an adaptation that benefits the purple-flowered relatives of white-flowered morphs, rather than providing a direct benefit to white-flowered individuals. Moreover, the postulated mechanism of kin selection could work only if the neighbouring individuals that benefit from the proximity of a white-flowered individual are related to it. In this study, white-flowered and pink-flowered individuals were not randomly distributed: only certain groups of populations hosted these rare colour morphs. These groups of populations might be considered as different kins of related individuals; certain kin would consist of only purple individuals, while other kin are characterised by high likelihood of spontaneous mutations affecting floral pigmentation. This hypothesis is consistent with the spatial genetic structure marked by aggregations of related individuals already demonstrated in O. mascula (Jacquemyn et al. 2008) and other species of the genus Orchis (Chung et al. 2005; Jacquemyn et al. 2006, 2007).

The presence of rare clear coloured-flowered individuals is widespread in European species of orchids. In $O$. mascula, both the presence of white- and pink-flowered individuals resulted in an increase in the fruit set of neighbouring pigmented flowers, which is in accordance with the mechanism proposed recently to explain the maintenance of floral colour polymorphism in this species (Dormont et al. 2010a, 2010b). We also identify important necessary conditions for future similar studies on other species. Some new observations recorded in this study are consistent with kin selection as the possible mechanism. We suggest that other comparative studies should be conducted on other species, in order to evaluate the importance of this mechanism in orchid pollination and that of other plant families.

\section{Acknowledgements}

We thank all the naturalists that helped us to find the rare white morphs. We also thank the International Orchid Workshop for giving us the opportunity to communicate our results.

\section{REFERENCES}

Ackerman JD, Carromero W (2005) Is reproductive success related to color polymorphism in a deception pollinated tropical terrestrial orchid? Carib J Science 41: 234-242.

Arditti J (1992) Phytochemistry. In: Arditti J (ed.) Fundamentals of orchid biology John Wiley and Sons, New York.

Bournérias M, Prat D (collectif de la Société Française d'Orchidophilie) (2005) Les orchidées de France, Belgique et Luxembourg (2nd edition). Biotope, Mèze (Collection Parthénope).

Brown BA, Clegg MT (1984) Influence of flower color polymorphism on genetic transmission in a natural population of the common morning glory, Ipomoea purpurea. Evolution 38: 769-803. 
Chittka L, Raine NE (2006) Recognition of flowers by pollinators. Curr Op Plant Biol 9: 428-435.

Chung MY, Nason JD, Chung MG (2005) Spatial genetic structure in populations of the terrestrial orchid Orchis cyclochila (Orchidaceae). Plant Syst Evol 254: 209-219.

Coberly LC, Rausher MD (2008) Pleiotropic effects of an allele producing white flowers. Evolution 62: 1076-1085.

Cozzolino S, Schiestl F, Muller A, De Castro O, Nardella AM, Widmer A (2005) Evidence for pollinator sharing in Mediterranean nectar-mimic orchids: absence of premating barriers? Proc Roy Soc Lond B 272: 1271-1278.

Delle-Vedove R, Juillet N, Bessière JM, Dormont L, Pailler T, Schatz B (2011) Colour-scent associations in a tropical orchid: three colours but two odours. Phytochemistry 72: 735-742.

Dormont L, Delle-Vedove R, Bessière JM, Hossaert-McKey M, Schatz B (2010a) Rare white-flowered morphs increase the reproductive success of common purple morphs in a food-deceptive orchid. New Phytol 185: 300-310.

Dormont L, Delle-Vedove R, Bessière JM, Hossaert-McKey M, Schatz B (2010b) Helping in food-deceptive orchids? A possible new mechanism maintaining polymorphism of floral signals. Plant Signal Behav 5: 526-527.

Dormont L, Bessière JM, Delle-Vedove R, Schatz B Diversity in colour-scent associations in three Mediterranean orchids. (in revision to Phytochemistry).

Epperson BK, Clegg MT (1987) Instability at a flower color locus in the morning glory. J Heredity 78: 346-352.

Galen C (1999) Why do flowers vary? The functional ecology of variation in flower size and form within natural plant populations. Bioscience 49: 631-640.

Gigord LDB, MacNair MR, Smithson A (2001) Negative frequency-dependent selection maintains a dramatic flower color polymorphism in the rewardless orchid Dactylorhiza sambucina (L.). Proc Nat Acad Sci USA 98: 6253-6255.

Guérin JC, Mathé JM, Merlet A (2004) Les orchidées de Poitou-Charentes et de Vendée. Biotope, Mèze (Collection Parthénope).

Hamilton WD (1964) The genetical evolution of social behavior. J Theor Biol 7: 1-52.

Jacquemyn H, Brys R, Vandepitte K, Honnay O, Roldan-Ruiz I (2006) Fine-scale genetic structure of life-history stages in the food-deceptive orchid Orchis purpurea. Mol Ecol 15: 2801-2808.

Jacquemyn H, Brys R, Vandepitte K, Honnay O, Roldan-Ruiz I, Wiegand T (2007) A spatially explicit analysis of seedling recruitment in the terrestrial orchid Orchis purpurea. New Phytol 176: 448-459.

Jacquemyn H, Brys R, Honnay O, Hermy M (2008) Effects of coppicing on demographic structure, fruit and seed set in Orchis mascula. Basic Appl Ecol 9: 392-400.

Jersakova J, Johnson SD, Kindlmann P (2006a) Mechanisms and evolution of deceptive pollination in orchids. Biol Rev 81: 219-235.

Jersakova J, Kindlmann P, Renner SS (2006b) Is the color dimorphism in Dactylorhiza sambucina maintained by differential seed variability instead of frequency-dependent selection? Folia Geobot 41: 61-76.

Johnson SD, Peter CI, Nilsson LA, Ågren J (2003) Pollination success in a deceptive orchid is enhanced by co-occurring rewarding "magnet" plants. Ecology 84: 2919-2927.

Jones KN, Reithel JS (2001) Pollinator-mediated selection on a flower color polymorphism in experimental populations of Antirrhinum (Scrophulariaceae). Am J Bot 88: 447-454.

Jouandoudet F (2004) A la découverte des orchidées sauvages d’Aquitaine. Biotope, Mèze (Collection Parthénope).
Juillet N, Delle-Vedove R, Dormont L, Schatz B, Pailler T (2010) Floral trait and reproductive success variations among colour varieties in a tropical deceptive orchid. Plant Syst Evol 289: 213-221.

Koivisto AM, Vallius E, Salonen V (2002) Pollination and reproductive success of two colour variants of a deceptive orchid, Dactylorhiza maculata (Orchidaceae). Nord J Bot 22: 53-58.

Lemoine B, Pessotto L (2007) Cephalanthera longifolia var. citrina observé en Tarn-et-Garonne. L'Orchidophile 38: 203-208.

Levin DA, Brack E (1995) Natural selection against white petals in Phlox. Evolution 49: 1017-1022.

Lunau K, Fieselmann G, Heuschen B, van de Loo A (2006) Visual targeting of components of floral colour patterns in flower-naive bumblebees (Bombus terrestris; Apidae). Naturwissenschaften 93: 325-328.

Nilsson LA (1983) Anthecology of Orchis mascula (Orchidaceae). Nord J Bot 3: 157-179.

Odell E, Raguso RA, Jones KN (1999) Bumblebee foraging responses to variation in floral scent and color in snapdragons (Anthirrhinum: Scrophulariaceae). Am Midl Nat 142: 257-265.

Raguso RA, Levin RA, Fooze SE, Holmberg MW, McDade LA (2003) Fragrance chemistry, nocturnal rhythms and pollination "syndromes" in Nicotiana. Phytochemistry 63: 265-284.

Schatz B (2006) Fine scale distribution of pollinator explains the occurrence of the natural orchid hybrid $\mathrm{xOrchis}$ bergonii. Ecoscience 13: 111-118.

Schatz B, Geoffroy A, Dainat B, Bessière JM, Buatois B, Hossaert-McKey M, Selosse MA (2010) A case study of modified interactions with symbionts in a hybrid Mediterranean orchid. Am J Bot 97: 1278-1288.

Schemske DW, Bierzychudek P (2007) Spatial differentiation for flower color in the desert annual Linanthus parryae: was Wright right? Evolution 61: 2528-2543.

Schiestl F (2005) On the success of a swindle: pollination by deception in orchids. Naturwissenschaften 92: 255-264.

Smithson A, MacNair MR (1997). Negative frequency-dependent selection by pollinators on artificial flowers without rewards. Evolution 51: 715-723.

Smithson A, Juillet N, MacNair MR, Gigord LD (2007) Do rewardless orchids show a positive relationship between phenotypic diversity and reproductive success? Ecology 88: 434-442.

Spaethe J, Tautz J, Chittka L (2001) Visual constraints in foraging bumblebees: flower size and color affect search time and flight behaviour. Proc Nat Acad Sci USA 98: 3898-3903.

Stanton ML, Snow AA, Handel SN, Bereczky J (1989) The impact of a flower-color polymorphism on mating patterns in experimental populations of wild radish (Raphanus raphanistrum L.). Evolution 43: 335-346.

Souche R (2004) Les orchidées sauvages de France. Éditions Les créations du Pélican. Paris.

Van der Cingel NA (1995) An atlas of orchid pollination-European orchids. Balkema, Rotterdam.

Wang H, Conchou L, Carbonell D, Imbert E, Schatz B (2013) Flower color polymorphic Iris lutescens (Iridaceae) in the light of plant-insect interaction. Phytochemistry 94: 123-134.

Warren J, Mackenzie S (2001) Why are all colour combinations not equally represented as flower-colour polymorphisms? New Phytol 151: 237-241.

Waser NM, Price MV (1981) Pollinator choice and stabilizing selection for flower color in Delphinium nelsonii. Evolution 35: 376-390.

Weiss MR (1995) Floral color-change - a widespread functional convergence. Am J Bot 82: 167-185. 